\title{
PARTISIPASI PEREMPUAN DALAM EKONOMI INKLUSIF
}

\author{
Elsy Renie \\ IAIN Batusangkar, Sumatera Barat, Indonesia \\ reniebts@gmail.com
}

\begin{abstract}
Abstrak
Gender inequality has become an issue in some countries. Although this inequality appear in various indicators such as economy, there is an improvement in the condition of women. The bias perception gives greater impact on women's work in all fields which are not as high position as men's work. The concept of inclusive economic development provides equal opportunities for men and women to actively participate in the economic sector. Then, the involvement of women in the inclusive economic sector still needs empowerment and literacy for the percentage of male involvement is more dominant than women. This research is a normative study that raises the theme of women's involvement in an inclusive economy. The aim of this research is to find out the women's participation in inclusive economy both in Indonesia and in other developing countries. This research concludes that the role of women in an inclusive economy has shown development. It can be seen from two indicators. First, the women's participation in employment is almost the same with men. Second, the woman's participation in education, despite they are still left behind by men, their existence in education field is increasing than previous year.
\end{abstract}

Keywords: Inclusive Economics, Women's Participation, Economics

\section{PENDAHULUAN}

Indeks pembangunan ekonomi Inklusif tigkat nasional tahun 2011-2017, terdiri dari tiga pilar yang meliputi pertumbuhan ekonomi, pemerataan pendapatan, pengurangan kemiskinan dan perluasan kesempatan. Indeks pembangunan yang telah dikeluarkan oleh berbagai institusi Internasional dirasa kurang mencerminkan tujuan pembangunan Indonesia secara spesifik, seperti tidak adanya fokus kepada isu gender, wilayah dan pendapatan, beberapa indikator tidak selaras dengan indikator pembangunan nasional.

Isu kesetaraan gender merupakan prioritas global saat ini, partisipasi perempuan ke depan dipandang akan menjadi pendorong pertumbuhan ekonomi inklusif, sekaligus berperan dalam menciptakan generasi yang siap menghadapi tantangan global. oleh karena itu, setiap wanita sudah seharusnya memperoleh akses yang tidak terbatas untuk membekali diri dengan pendidikan yang berkualitas, kesehatan, dan kemampuan berusaha yang memadai, sehingga dapat menempatkan perempuan pada posisi yang seimbang dengan pria dalam pembangunan.

Pemerintah sendiri telah memberikan perhatian kepada program-program pemberdayaan perempuan sejak dini dengan alokasi anggaran untuk sektor pendidikan maupun kesehatan. Selain itu, Pemerintah telah memperluas sasaran penerima Program Keluarga Harapan (PKH), juga beberapa program lain seperti Program Pendidikan Anak Usia Dini (PAUD) yang dilakukan untuk meningkatkan perluasan dan pemerataan akses PAUD bermutu berkesetaraan gender, dan berwawasan pendidikan.

\section{HASIL PENELITIANDAN PEMBAHASAN}

\section{Ekonomi Inklusif}

Elena Ianchovichina and Susanna Lundstrom (2009) mengemukakan 
pendapatnya mengenai ekonomi inklusif, Kim Eric Bettcher: (2015:1), "Economic inclusion refers to equality of opportunity for all members of society to participate in the economic life of their country as employees, entrepreneurs, consumers, and citizens. Individuals of all social backgrounds and income strata should have opportunities to participate in the economy and reap the benefits of their participation. Fundamentally, inclusion entails access without bias to markets, resources, and opportunities inclusion entails access without bias to markets, resources, and opportunities.

Perekonomian Indonesia sedang menghadapi tantangan besar. Tantangan ini terkait upaya mengubah pola pertumbuhan ekonomi yang sarat tergantung pada sumber daya alam yang berlimpah dan upah tenaga kerja yang murah, menjadi pola pertumbuhan ekonomi yang lebih inklusif (inclusive growth) serta ramah lingkungan dan berkelanjutan (green growth). Pertumbuhan yang inklusif didefinisikan sebagai pertumbuhan yang tidak hanya menghasilkan peluang ekonomi, tetapi juga menjamin akses yang adil bagi seluruh anggota masyarakat terhadap peluang ekonomi yang tercipta. Pertumbuhan yang inklusif memungkinkan semua anggota masyarakat untuk berpartisipasi dan mengambil manfaat dari pertumbuhan dan pembangunan ekonomi atas dasar kesetaraan terlepas dari latar belakang sosial ekonomi yang berbeda (Hill, Khan, Zhuang 2012: 2)

Permasalahan kemiskinan dan ketimpangan sosial ekonomi antar individu maupun wilayah saat ini masih dialami oleh Indonesia dan negara-negara lain di dunia. Fenomena kemiskinan dan ketidakadilan global ditunjukkan dengan adanya 20\% populasi dunia yang mampu menikmati lebih dari $70 \%$ pendapatan dunia, atau dengan kata lain sebanyak $80 \%$ populasi dunia hanya mampu menikmati kurang dari $30 \%$ pendapatan dunia. Oxfam (2017) dalam hasil surveinya menyebutkan bahwa meski terjadi pertumbuhan ekonomi yang cukup baik di Indonesia, namun pertumbuhan ekonomi tersebut tidak mampu mengurangi ketimpangan. Meskipun dalam satu tahun terakhir secara umum terjadi penurunan ketimpangan, namun fenomena ketimpangan tersebut masih terjadi hampir merata di seluruh Indonesia. DKI Jakarta, DI Yogyakarta, Gorontalo, dan Papua adalah contoh dari wilayah di Indonesia yang memiliki ketimpangan tertinggi dengan nilai indeks Gini ratio mencapai sekitar 0,43. (Eri Hariyanto,

https://www.djppr.-

kemenkeu.go.id/)

United Nation Development

Program (UNDP) memantau pembangunan manusia setiap negara dengan menerbitkan Human Development Index (HDI) untuk mengkategorikan setiap negara menjadi negara terbelakang, berkembang, dan maju. Dalam penilaian tahun 2014, Indonesia menduduki peringkat 108 dari 187 negara dan dikategorikan negara berkembang. Di kawasan ASEAN, posisi Indonesia masih di bawah Singapura, Brunei, Malaysia, dan Thailand. Dengan pembangunan ekonomi inklusif terutama pada sektor kesehatan dan pendidikan diharapkan dapat meningkatkan taraf kehidupan masyarakat sekaligus indeks pembangunan manusia.

Struktur penduduk Indonesia ditandai dengan tingginya proporsi penduduk usia produktif. Pada tahun 2018, penduduk usia produktif di Indonesia mencapai 68,6 persen atau 181,3 juta jiwa dengan angka ketergantungan usia muda dan tua yang rendah, yaitu 45,7. Perubahan struktur penduduk ini akan membuka peluang bagi Indonesia untuk mendapatkan bonus demografi (demographic dividend) yang dalam jangka menengah dan panjang akan mendorong pertumbuhan ekonomi yang tinggi dan menghantarkan Indonesia menjadi negara berpenghasilan menengah ke atas. Bonus demografi ini akan diperoleh dengan els prasyarat utama tersedianya sumber daya manusia (SDM) yang 
berkualitas dan berdaya saing. (RPJMN 2020-2025;88)

Capaian utama pembangunan kesetaraan gender dan pemberdayaan perempuan ditandai dengan meningkatnya Indeks Pembangunan Gender (IPG) dan Indeks Pemberdayaan Gender (IDG). IPG mengalami peningkatan dari 90,82 di tahun 2016 menjadi 90,99 di tahun 2018. Hal ini berarti kesenjangan pembangunan antara perempuan dan laki-laki semakin mengecil di beberapa bidang pembangunan. Sementara itu, IDG meningkat dari 71,39 di tahun 2016 menjadi 71,74 di tahun 2017. Peningkatan capaian IDG didukung oleh meningkatnya jumlah perempuan sebagai tenaga profesional dan sumbangan pendapatan pekerja perempuan. (RPJMN 2020-2025;298).

Beberapa ahli ekonomi berpendapat bahwa pertumbuhan saja belum cukup untuk menyelesaikan masalah kemiskinan dan ketimpangan ekonomi. Hal ini disebabkan karena pertumbuhan ekonomi biasanya hanya mementingkan pertumbuhan Gross Domestic Product (GDP) suatu negara tetapi kurang memerhatikan masalah penyerapan tenaga kerja, pengurangan kemiskinan dan pemerataan pendapatan. Akibatnya pertumbuhan ekonomi yang terjadi justru menambah jumlah penduduk miskin dan memperlebar ketimpangan pendapatan antar individu. Menurut Eric Maskin (penerima penghargaan Nobel Ekonomi, 2007) mengukur hasil pembangunan hanya dari pertumbuhan ekonomi semata akan meniadakan terjadinya pemerataan dalam masyarakat untuk menikmati hasil pembangunan.

Negara-negara berkembang, termasuk Indonesia, banyak yang terjebak dalam ekonomi ekslusif yaitu keinginan untuk mengejar taraf perekonomian negara-negara maju dengan mendorong pertumbuhan ekonomi yang tinggi terutama dengan memacu pertumbuhan ekonomi sektor sekunder (industri manufaktur) dan tersier (industri jasa). Kedua sektor tersebut memberikan kontribusi yang tinggi dalam pertumbuhan ekonomi tetapi hanya menyerap sedikit tenaga kerja. Disisi lain yakni di sektor primer, terutama sektor pertanian, kurang mendapatkan perhatian padahal sektor tersebut banyak sekali menyerap tenaga kerja. Akibatnya terjadilah ketimpangan pendapatan antar penduduk yang bekerja pada sektor pertanian dengan sektor manufaktur dan jasa. (www.djppr.kemenkeu.go.id)

Pertumbuhan ekonomi yang tinggi tidak menjamin semua masyarakat menerima manfaat yang sama. Untuk memperoleh ukuran yang mampu menjelaskan pertumbuhan ekonomi dan masalah sosial, beberapa lembaga internasional seperti Asian Development Bank (ADB), World Economic Forum (WEF) dan United Nation Development Programme (UNDP) menciptakan suatu set variabel dan formula untuk melakukan pengukuran pertumbuhan ekonomi alternatif yang menekankan pada kesetaraan akses terhadap peluang ekonomi bagi semua lapisan masyarakat. Ukuran ini disebut dengan pertumbuhan ekonomi inklusif.

Menurut ADB (2011), (Agnes:2018:1) ada beberapa alasan mengapa pertumbuhan harus inklusif yaitu:

1. Pertimbangan kesetaraan dan keadilan, pertumbuhan seharusnya terdistribusi dan inklusif di seluruh lapisan masyarakat dan daerah.

2. Pertumbuhan dengan ketimpangan yang persisten dapat membahayakan kondisi sosial, seperti orang miskin dan pengangguran lebih rentan masuk dalam aktivitas kriminal, perempuan lebih rentan ke prostitusi, dan tenaga kerja anak yang tidakdiharapkan.

3. Ketimpangan dalam hasil dan akses yang berkelanjutan dapat mengganggu stabilitas politik dan struktur sosial sehingga mengurangi potensi pertumbuhan. 


\section{Arah Pengembangan Ekonomi Inklusif Indonesia}

UUD 1945 menjamin hak semua warga negara atas kemerdekaan, kesempatan yang sama dan perlindungan dari segala bentuk diskriminasi, termasuk perlindungan khusus kepada kelompok rentan. Indonesia telah menegaskan komitmennya bagi penerapan prinsip-prinsip ini dalam pekerjaan melalui ratifikasi beberapa Konvensi International Labour Organisation (ILO) tentang upah dan nondiskriminasi di tempat kerja.

Walau demikian, hambatan terhadap akses ke pekerjaan layak masih ada. Perempuan dan kelompok marginal lainnya masih menghadapi berbagai rintangan, khususnya dalam perekrutan, remunerasi, jam kerja, promosi, peluang pengembangan diri, dan hal-hal lainnya. Kondisi ini terlihat dari tingkat partisipasi angkatan kerja perempuan (TPAK), yang masih bertahan di rata-rata $50 \%$ selama 20 tahun terakhir, sementara partisipasi laki-laki telah meningkat menjadi $84 \%$. Secara rata-rata, perempuan juga masih mendapat $77 \%$ dari upah yang didapat laki-laki untuk jenis pekerjaan yang sama. Partisipasi kerja di antara para penyandang disabilitas juga rendah $(74,4 \%)$, dan mayoritas dari mereka bekerja di sektor informal karena kesulitan mengakses kerja formal dan/atau lingkungan kerja yang inklusif. (indonesiadevelopmentforum.com)

Indonesia merupakan satu-satunya negara di Asia Tenggara yang masuk dalam G-20, ukurannya adalah Produk Domestik Bruto (PDB). Perekonomian Indonesia mampu tumbuh sekitar 4-6 persen per tahun selama dekade terakhir ini, di saat negaranegara maju mengalami perlambatan ekonomi. Di sisilain, ketimpangan pendapatan naik dari 0,363 tahun 2005 menjadi 0,394 di September 2016. Credit Suisse, sebagaimana dikutip dari Katadata (2017) mencatat bahwa 1 persen orang terkaya di Indonesia menguasai 49 persen kekayaan nasional. Sementara, 10 persen orang terkaya menguasai 77 persen total kekayaan nasional.

Sebagai ukuran pertumbuhan yang multidimensional, ekonomi inklusif tidak hanya didekati menggunakan hubungan antara pertumbuhan ekonomi dengan faktor ekonomi lainnya, namun juga keterkaitan antara pertumbuhan ekonomi dengan faktorfaktor sosial seperti gender, pendidikan, fertilitas, sebagainya. Garcia, Brio, dan Victorio (2018) menunjukkan bahwa faktor gender dapat mendukung pertumbuhan ekonomi inklusif bila perempuan diberikan akses yang sama dengan laki-laki untuk memperoleh pendidikan yang lebih tinggi, akses lebih bebas ke lapangan kerja, serta peningkatan partisipasi perempuan dalam politik.

Indonesia tidak mulai dari awal, Indonesia adalah ekonomi yang bergerak dengan segala kekuatan dan kelemahannya. Dalam kaitan dengan inklusi Indonesia sedang bergumul dengan sejumlah besar penduduk yang berada di pinggir kemiskinan. Oleh karena itu, ekspansi besarbesaran dari lapangan kerja yang lebih produktif sangat diperlukan. Dalam kaitan dengan keberlanjutan juga dihadapi banyak gejala yang memprihatinkan. (Simandjuntak: 2012)

Menurut Agnes, dkk (2018) Pertumbuhan inklusif tidak hanya dilihat dari pertumbuhan ekonomi semata. Faktor lain terkait pemerataan, kesejahteraan, dan pertumbuhan yang berkelanjutan menjadi penting untuk diperhatikan. Jika hanya melihat pertumbuhan ekonomi, dalam jangka waktu 2010-2015, perekonomian regional di 33 provinsi di Indonesia mampu tumbuh sekitar 4-6 persen. Pertumbuhan ini tergolong cukup tinggi, bahkan termasuk yang tertinggi di negara G20. Angka ini hanya melihat pertumbuhan akumulasi perekonomian yang terjadi, tanpa memperhatikan siapa yang menerima manfaat dari pertumbuhan kegiatan ekonomi tersebut. Ketimpangan pendapatan masih terjadi dan bervariasi antar provinsi. Jadi, 
pertumbuhan regional yang tinggi ini tidak menjamin kesejahteraan merata di 33 provinsi. Padahal, salah satu tujuan utama pembangunan adalah memajukan kesejahteraan umum. Oleh karena itu, perkembangan indikator kesejahteraan perlu diperhatikan untuk melihat kualitas pertumbuhan ekonomi yang terjadi.

\section{Perempuan dan Ekonomi yang Inklusif di Indonesia}

Dua dekade belakangan telah banyak organisasi internasional, dan pemimpin dunia yang mengakui bahwa pemberdayaan ekonomi perempuan sangat penting untuk pertumbuhan ekonomi dan stabilitas. Berdasarkan analisis dari PBB, IMF, EOCD, bank dunia dan lembaga internasional lainnya menunjukkan potensi pertumbuhan ekonomi yang menyusul dengan meningkatnya literasi ekonomi perempuan. (Gayle Tzemach Lemmon:2017, 4)
Meskipun kesenjangan gender dalam pekerjaan global terus mengalami stagnasi sejumlah besar bukti menegaskan bahwa manfaat ekonomi dari mempromosikan inklusi ekonomi perempuan di ini substansial, Bukti empiris menunjukkan bahwa peran perempuan untuk berkontribusi dapat meningkatkan ekonomi dalam empat cara: ekonomi yang lebih tinggi, pertumbuhan ekonomi, hasil pembangunan yang lebih menguntungkan, diversivikasi ekonomi yang lebih besar, dan ketimpangan pendapatan yang lebih rendah.

Bekal keterampilan yang didapatkan pada pelatihan kerja akan meningkatkan keahlian dan kemampuan perempuan sehingga dapat memperluas pilihan dan peluang kerja serta dapat berpartisipasi secara setara dengan laki-laki di pasar tenaga kerja. Pada akhirnya, dengan semakin terbukanya pilihan dan peluang tersebut akan menaikkan taraf hidup perempuan menjadi lebih sejahtera.

Tabel. 1

Persentase Penduduk 15 Tahun ke Atas yang Mendapatkan Pelatihan Kerja, 2011-2015:

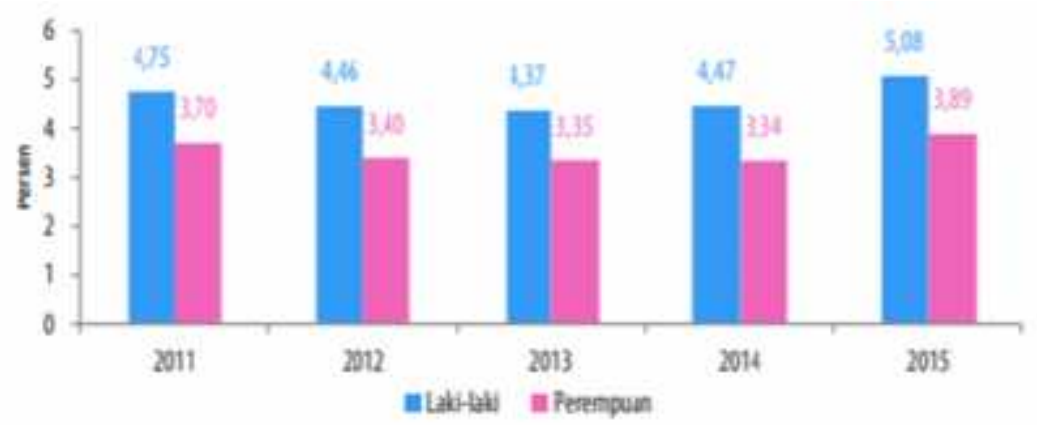

(Sumber: Sakernas 2011-2015)

Hasil Survei Angkatan Kerja Nasional pada tahun 2015 menyebutkan bahwa terdapat 32,17 persen perempuan yang berusia 15 tahun keatas (usia kerja) yang menjadi pengusaha, baik yang berusaha sendiri tanpa bantuan pekerja maupun dengan bantuan pekerja. Meskipun secara jumlah cukup besar namun akses perempuan terhadap kredit amat rendah. (Kemenppa: 2015:33)
Pembangunan ekonomi sampai saat ini, meskipun telah menghasilkan berbagai kemajuan, masih jauh dari cita-citanya untuk mewujudkan perekonomian yang tangguh dan menyejahterakan seluruh lapisan masyarakat. Oleh karena itu, tantangan besar kemajuan perekonomian 20 tahun mendatang adalah meningkatkan pertumbuhan ekonomi yang cukup tinggi dan berkualitas secara berkelanjutan untuk 
mewujudkan secara nyata peningkatan kesejahteraan sekaligus mengurangi ketertinggalan dari bangsa-bangsa lain yang lebih maju. (RPJP:81) Dibeberapa negara di dunia masih terjadi kesenjangan upah antara laki-laki dan perempuan, termasuk kesenjangan dalam pekerjaan dan tanggung jawab. (ILO: 2011:1, UNTAD:2012:1). Preferensi penerima kerja juga lebih tinggi terhadap laki-laki dibandingkan perempuan, karena perempuan dianggap memiliki ikatan kerja yang lemah dibandingkan laki-laki (Anker dan Heir: 1985, kabeer:2012)

Meningkatnya kualitas sumber daya manusia, termasuk peran perempuan dalam pembangunan. Secara umum peningkatan kualitas sumber daya manusia Indonesia ditandai dengan meningkatnya indeks pembangunan manusia (IPM) dan indeks pembangunan gender (IPG), serta tercapainya penduduk tumbuh seimbang.

Pembangunan sumber daya manusia memiliki peran yang sangat penting dalam mewujudkan manusia Indonesia yang maju dan mandiri sehingga mampu berdaya saing dalam era globalisasi. Dalam kaitan itu, pembangunan sumber daya manusia diarahkan pada peningkatan kualitas sumber daya manusia Indonesia yang antara lain ditandai dengan meningkatnya indeks pembangunan manusia (IPM) dan indeks pembangunan gender (IPG), serta tercapainya penduduk tumbuh seimbang yang ditandai dengan angka reproduksi neto (NRR) sama dengan 1, atau angka kelahiran total (TFR) sama dengan 2,1.

Pembangunan pemberdayaan perempuan dan anak diarahkan pada peningkatan kualitas hidup dan peran perempuan, kesejahteraan, dan perlindungan anak di berbagai bidang pembangunan penurunan jumlah tindak kekerasan, eksploitasi, dan diskriminasi terhadap perempuan dan anak serta penguatan kelembagaan dan jaringan pengarusutamaan gender dan anak di tingkat nasional dan daerah, termasuk ketersediaan data dan statistik gender.

Taraf pendidikan penduduk Indonesia mengalami peningkatan yang, antara lain, diukur dengan meningkatnya angka melek aksara penduduk usia 15 tahun ke atas, meningkatnya jumlah penduduk usia 15 tahun ke atas yang telah menamatkan pendidikan jenjang SMP/MTs ke atas; meningkatnya rata-rata lama sekolah; dan meningkatnya angka partisipasi sekolah untuk semua kelompok usia. Walaupun demikian, kondisi tersebut belum memadai untuk menghadapi persaingan global yang makin ketat pada masa depan. Hal tersebut diperburuk oleh tingginya disparitas taraf pendidikan antar kelompok masyarakat, terutama antara penduduk kaya dan miskin, antara wilayah perkotaan dan perdesaan, antardaerah, dan disparitas gender.

Tabel. 2

Persentase Penduduk 15 Tahun Ke Atas yang masih Sekolah Menurut Jenis Kelamin, 2011-2015

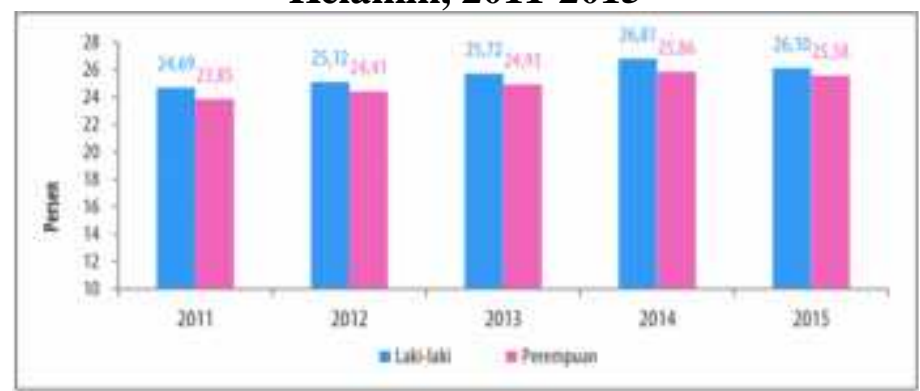

Dilihat dari tingkat pendidikan maka secara umum terlihat bahwa perempuan memiliki tingkat pendidikan yang lebih rendah jika dibandingkan dengan laki-laki.
Seperti yang ditunjukkan pada Gambar 2.1 yang memperlihatkan persentase penduduk 15 tahun ke atas yang masih sekolah dimana persentase perempuan yang masih sekolah 
dari kurun waktu 2011-2015 selalu lebih rendah jika dibandingkan dengan laki-laki. Namun, pada kurun waktu tersebut terlihat bahwa persentase perempuan yang masih sekolah mengalami peningkatan, sehingga kesenjangan antara laki-laki dan perempuan semakin mengecil (Kemenppa:2015)

Di banyak negara berkembang, kerap terdapat perbedaan besar antara laki-laki dan perempuan dalam hal akses, kebutuhan, dan pilihan mereka terhadap jasa keuangan sehingga dalam mengembangkan akses terhadap layanan keuangan adalah penting untuk mengenali perbedaan-perbedaan tersebut. (UNESCO: 2010:3) usaha-usaha yang dikelola perempuan cendrung usaha kecil dan biasanya pada sektor yang kurang menguntungkan di banding laki-laki. Sementara perkembangan dunia internasional telah membuka berbagai lapangan kerja baru dan perempuan lebih banyak ditemukan bekerja pada sektor yang kurang menguntungkan dan tidak banyak memberikan jaminan social (UNTAD: 2012:1)

Di Indonesia, laki-laki dan perempuan memiliki kesempatan yang sama untuk mempunyai rekening tabungan. Namun, motivasi utama laki-laki saat membuka rekening tabungan bank lebih sering adalah untuk memperoleh kredit, sedangkan perempuan menabung demi keperluan mendatang. Dalam hal kepemilikan asuransi, perempuan lebih sering membeli asuransi pendidikan, sementara laki-laki lebih memilih asuransi jiwa, dan pada taraf tertentu juga memiliki asuransi harta benda.

Keuangan inklusif ini merupakan strategi pembangunan nasional untuk mendorong pertumbuhan ekonomi melalui pemerataan pendapatan, pengentasan kemiskinan serta stabilitas sistem keuangan. Strategi yang berpusat pada masyarakat ini perlu menyasar kelompok yang mengalami hambatan untuk mengakses layanan keuangan. Strategi keuangan inklusif secara eksplisit menyasar kelompok dengan kebutuhan terbesar atau belum dipenuhi atas layanan keuangan yaitu tiga kategori penduduk (orang miskin berpendapatan rendah, orang miskin bekerja/miskin produktif, dan orang hampir miskin) dan tiga lintas kategori (pekerja migran, perempuan, dan penduduk daerah tertinggal).

\section{KESIMPULAN DAN REKOMENDASI}

Peranan perempuan dalam ekonomi inklusif, jika dilihat dalam dua indikator, yaitu sektor ketenagakerjaan dan sektor pedidikan, sudah menampakkan perkembangan, kondisi ini bisa terlihat dari partisipasi perempuan dalam ketenaga kerjaan yang hampir menyamai posisi lakilaki, demikian juga kondisi perempuan dalam pendidikan, posisi perempuan masih berada di belakang laki-laki, dengan persentase perbedaan yang cukup kecil di belakang kaum laki-laki, karena pendidikan adalah hal yang cukup signifikan dan juga sebagai gerbang awal dalam mendapatkan kesempatan berkerja yang lebih kompetitif dan layak bagi perempuan, yang merupakan pilar pembangunan ekonomi yang inklusif, namun perempuan bekerja belum menduduki sektor-sektor yang menguntungkan. Peran perempuan dalam ekonomi yang inklusif membutuhkan keberpihakan dan juga literasi dari pemerintah.

\section{DAFTAR KEPUSTAKAAN}

Agnes Vera Yanti Sitorus, Ade Marsinta Arsani, 2018, A Comparative Study of Inter-Provincial Inclusive Economic Growth in Indonesia 2010-2015 with Approach Methods of ADB, WEF, and UNDP, Jurnal Perencanaan PembangunanThe Indonesian Journal of Development Planning

Djisman Simandjuntak et al, Ekonomi Inklusif dan Berkelanjutan di Era Pengetahuan Terbuka Komite Ekonomi Nasional Kementerian Koordinator Bidang Perekonomian RI 
Gayle Tzemach Lemmon et.al, Building Inclusive Economies How Women's Economic Advancement Promotes Sustainable Growth, the Council on Foreign Relations.U.S (www.cfr.org)

Kementerian Pemberdayaan Perempuan dan Perlindungan Anak, 2015, statistik gender tematik - potret ketimpangan gender dalam ekonomi, CV. Lintas Khatulistiwa

Kim Eric Bettcher, Teodora Mihaylova, Economic Inclusion, 2015, Leveraging Markets and Entrepreneurship to Extend Opportunity, Center for International Private Enterprise

Kementrian PPN/ BAPPENAS, RENCANA
PEMBANGUNAN
MENENGAH NASIONAL 2020-2024

UNCTAD secretariat. Inclusive and gendersensitive development paths, Development-centred globalization: Towards inclusive and sustainable growth and development.

Zhuang, J. (2010). Poverty, Inequality, and Inclusive Growth in Asia: Measurement, Policy Issues, and Country Studies. Manila: Asian Development Bank.

Naila Kabeer, Women's economic empowerment and inclusive growth: labour markets and enterprise development

Elena Ianchovichina and Susanna Lundstrom, "What is Inclusive Growth." World Bank. February 10, 2009 http://siteresources.worldbank. 